AGNIESZKA SZOSTAK* - KRAKÓW

\title{
MISJA JAKO ELEMENT ZARZĄDZANIA STRATEGICZNEGO MUZEUM
}

\section{Wprowadzenie}

W języku polskim pojęcie misji (z łac. missio - posłanie) ma kilka znaczeń - ,posłannictwo, ważne odpowiedzialne zadanie do spełnienia”, ,przedstawicielstwo państwa lub organizacji delegowane w specjalnym celu do innego państwa; też: siedziba tego przedstawicielstwa", działalność instytucji religijnych podejmowana w celu rozpowszechniania jakiejś religii i pozyskania jej nowych wyznawców; też: placówka prowadząca taką działalność1. W znaczeniu prawnym odniesienia do misji znajdują się w ustawie o muzeach ${ }^{2}$, której artykuł 1. określa definicje i cele funkcjonowania muzeów, natomiast artykuł 2. sposób ich realizacji (rodzaje realizowanych zadań). Zapisy te wyznaczają ogólną misję polskich muzeów. Również w wielu dyskusjach na temat bieżących zagadnień z zakresu muzealnictwa pojawia się określenie misji, np. edukacyjna, upowszechnieniowa, naukowa. Pojęcie to jest też elementem zarządzania strategicznego w którym istotne jest określenie misji dla organizacji - tzn. Organizacji w znaczeniu „grupy ludzi, którzy współpracują ze sobą w sposób uporządkowany i skoordynowany, aby osiągnąć pewien zestaw celów"3.

Celem artykułu jest dokonanie przeglądu misji polskich muzeów. Na podstawie danych, przede wszystkim stron internetowych muzeów znajdujących się w bazie Narodowego Instytutu Muzealnictwa i Ochrony Zbiorów, a także ich Biuletynów Informacji Publicznej przeanalizowane zostanie ilościowo i jakościowo zjawisko występowania misji muzeum, rozumiane jako element zarządzania. Sta-

*Agnieszka Szostak - mgr zarządzania kulturą; doktorantka na Wydziale Zarządzania i Komunikacji Społecznej Uniwersytetu Jagiellońskiego; kierownik Sekcji Strategii i Rozwoju Muzeum Historycznego Miasta Krakowa, e-mail: agnieszka.szostak@uj.edu.pl

${ }^{1}$ Stownik Języka Polskiego PWN, http://sjp.pwn.pl/szukaj/misja.html (dostęp: 01.02.2016).

${ }^{2}$ Ustawa o muzeach z dnia 21 listopada 1996 r., Dz. U. 1997 Nr 5 poz. 24, http://isap.sejm.gov. pl/DetailsServlet?id=WDU19970050024 (dostęp: 25.09.2015).

${ }^{3}$ R.W Griffin, Podstawy zarzadzania organizacjami, Warszawa 1998, s. 35. 
nowić to będzie pierwszy, wstępny etap projektu badawczego dotyczącego zarządzania muzeami w Polsce, ze szczególnym uwzględnieniem zarządzania strategicznego.

Należy zwrócić uwagę, że przedmiotem analizy są misje, które zostały określone przez dane instytucje, a także znajdują się na ich stronach internetowych (ewentualnie w Biuletynach Informacji Publicznej). Nie wyklucza to istnienia podobnych zapisów w innych muzeach i ich dokumentach programowych, np. strategiach, jednak ze względu na ograniczony dostęp do nich (jedynie 8 muzeów udostępnia swoje strategie) wymaga to zastosowania innych technik badawczych, i jest planowane w kolejnych etapach badania. W toku dalszych prac, autorka przewiduje opracowanie ankiety, skierowanej do muzeów, a także wywiady z przedstawicielami kadry zarządzającej wybranych muzeów. Stanowić to będzie uzupełnienie obecnej, wstępnie prowadzonej analizy.

Dokonując przeglądu literatury w tym zakresie należy zauważyć, że zagadnienie misji w zarządzaniu muzeów nie było szerzej w Polsce badane. Właściwie pierwszym szerszym opracowaniem z zakresu zarządzania muzeami jest praca Katarzyny Barańskiej ${ }^{4}$, w której autorka analizuje pojęcie misji i jej znaczenie na przykładzie Muzeum Etnograficznego w Krakowie, natomiast literatura z zakresu zarządzania wskazuje przede wszystkim znaczenie formułowania misji w zarządzaniu instytucją kultury, a także wskazówki co do poprawnego jej formułowania. Badania pilotażowe dotyczące wykorzystywania przez muzea narzędzi zarządzania, w tym zarządzania strategicznego, prowadził Łukasz Gawel's, natomiast Marcin Szeląg w Raporcie o edukacji prezentował zagadnienie misji muzeów w kontekście prowadzonej przez nie edukacji ${ }^{6}$. Szerzej zarządzaniem strategicznym w instytucjach kultury zajmował się Mateusz Lewandowski, który poza analizą teoretyczną przeprowadził również badania w kilku różnego typu instytucjach kultury (m.in. domach i centrach kultury, fundacji) ${ }^{7}$. Zajmował się również badaniem barier przy opracowaniu planów strategicznych, zawierających misję instytucji. Jednak bardzo mała próba - zaledwie 6 instytucji kultury, w tym ani jednego muzeum, nie pozwala na dokonanie uogólnień. Tematyka ta (tj. zarządzania strategicznego) nie jest również poruszana przez Narodowy Instytut Muzealnictwa i Ochrony Zbiorów, który w obszernym badaniu muzeów w ramach prowadzonego projektu Statystyka muzeów ${ }^{8}$ nie zawarł pytań dotyczących misji muzeów, czy strategii. Jedynym wątkiem, jaki pojawił się w pierwotnej wersji

\footnotetext{
${ }^{4}$ K. Barańska, Muzeum etnograficzne. Misje, struktury, strategie, Kraków 2004.

${ }^{5}$ Ł. Gaweł, Muzeum w przestrzeni publicznej. Przyczynek do praktyki zarzadzania instytucjami kultury, „Zarządzanie publiczne”, 15 (2011) z. 3, s. 54 i 59.

${ }^{6}$ Wyniki przeprowadzonego badania wskazywały, że ankietowani utożsamiali pojęcie misji ze statutem, regulaminem organizacyjnym, bądź też bieżącą działalnością muzeum. Por. Edukacja muzealna w Polsce. Sytuacja, kontekst, perspektywy rozwoju. Raport o stanie edukacji muzealnej w Polsce. http://nimoz.pl/pl/wydawnictwa/wydawnictwa-nimoz/raport-o-stanie-edukacji-muzealnej-w-polsce-4 (dostęp: 4.10.2015).

${ }^{7}$ M. Lewandowski, Zarzadzanie strategiczne w instytucjach kultury, Katowice 2013, s. 123 i nast.

${ }^{8}$ Więcej na temat projektu na https://statystykamuzeow.nimoz.pl/\# (dostęp: 01.02.2016).
} 
ankiety, jest pytanie dotyczące posiadania strategii digitalizacji, co związane było z realizacją programu Polska Cyfrowa, jednak w kolejnej edycji badania pytanie to już nie występuje. Wyniki przeprowadzonych badań ankietowych nie zostały opublikowane ${ }^{9}$. Dlatego zgodzić się trzeba ze stwierdzeniem, że:

konieczne jest w szczególności pogłębienie badań dotyczących instytucji kultury, w tym dotyczące zastosowania poszczególnych instrumentów planowania strategicznego ${ }^{10}$.

\section{Pojęcie misji w zarządzaniu strategicznym}

Misja organizacji nazywamy „zestaw względnie trwałych dążeń, celów, na które zorientowane są lub powinny być działania podejmowane przez jej uczestników; to samookreślenie się organizacji poprzez odpowiedź na pytania: Po co organizacja istnieje? Do czego ma dążyć? Co ma osiągnąć? Czyje i jakie potrzeby powinna zaspokajać? Jakie jest jej społeczne posłannictwo?"11

A więc misja „,definiuje pewien stan postulowany:

- Kim chcemy być?

- Dla kogo istniejemy?

- Co mamy robić?"12

Można więc stwierdzić, że „misja jest precyzyjnym wyrażeniem (...) dalekosiężnych zamierzeń i aspiracji organizacji”' ${ }^{\prime 3}$. Ponadto „misja instytucji kultury winna korespondować z ogólną misją propagowania kultury ustalaną przez publiczny organ założycielski (...)"14. R. Koch dokonuje ważnego rozgraniczenia pomiędzy posiadaniem misji (w formie spisanego dokumentu w firmie) a poczuciem misji pracowników w ich codziennej pracy w firmie. Stwierdza, że „koncepcja misji i poczucia misji dotyczy wszystkich aspektów kierunków działania firmy (...)"15. Model Ashridga misji firmy, na który składają się cztery jej parametry: cel, wartość, strategia i standardy zachowania został, w przypadku muzeów, zaadoptowany przez K. Barańską na potrzeby sformułowania misji Muzeum Etnograficznego w Krakowie ${ }^{16}$.

\footnotetext{
${ }^{9}$ Informacje te uzyskałam podczas wywiadów przeprowadzonych z pracownikami Narodowego Instytutu Muzealnictwa i Ochrony Zbiorów w październiku 2015 r.

${ }^{10} \mathrm{M}$. Lewandowski, Czynniki utrudniające samodzielne opracowywanie planów strategicznych przez pracowników instytucji kultury, w: Zarzadzanie w instytucji kultury, red. Ł. Wróblewski, Warszawa 2014, s. 65.

${ }^{11}$ Zarzadzanie. Teoria i praktyka, red. A.K. Koźmiński,W. Piotrowski Warszawa 2000 s. 759.

${ }^{12} \mathrm{G}$. Matt, Muzeum jako przedsiębiorstwo. Latwo i przystępnie o zarządzaniu instytucją kultu$r y$, Warszawa 2006, s. 44.

${ }^{13}$ K. Obłój, Strategia organizacji, Warszawa 1999, s. 235.

${ }^{14}$ Zarzadzanie w kulturze, sztuce i turystyce kulturowej, red. J. Gołuchowski, Z. Spyra, Warszawa 2014, s. 165.

${ }^{15}$ Zob. hasło misja w: Stownik zarządzania i finansów. Narzędzia, terminy, techniki od A do Z, red. R. Koch, Kraków 1997 s. 147-148.

${ }^{16} \mathrm{~K}$. Barańska, Wiatr w żaglach, czyli misja Muzeum Etnograficznego im. Seweryna Udzieli w Krakowie, „Zarządzanie w kulturze”, 7 (2006) s. 15-23.
} 
Misja jest elementem planu strategicznego organizacji, rozumianego jako efekt procesu długofalowego planowania ukierunkowanego na określanie i realizację celów organizacji ${ }^{17}$. Na ów proces składa się kolejno określenie wizji, misji, a następnie wyznaczenie strategii (określenie celów strategicznych).

Misja obok wizji stanowi początek procesu zarządzania strategicznego „i stanowi punkt wyjścia do określenia celów i zadań”18. „Jest kierowana zarówno do wnętrza instytucji, jak i jej otoczenia" ${ }^{19}$.

Obok misji pojawia się pojęcie wizji. Wizja to „inspirująca koncepcja przyszłości firmy, marzenie o jej przyszłym kształcie i sukcesach, obraz tego, czym może być (...), to dalekosiężne aspiracje lidera związane z jego firmą (...)"20. Albo inaczej ,to określenie stanu organizacji, jaki ma być osiągnięty przez nią w przyszłości” (...). Wizja różni się od misji sposobem określenia organizacji. Misja określa, jak dojść do postawionego celu, natomiast wizja określa, do jakiego celu mamy zmierzać ${ }^{21}$.

Pojęcie strategii organizacji jest jednym z podstawowych z zakresu zarządzania, a co za tym idzie istnieje wiele jego definicji. Odnoszą się one do strategii jako planu realizowanych działań, jako decyzji podejmowanych przez kierownictwo organizacji, czy celów przez to kierownictwo wyznaczanych. Na potrzeby tego artykułu autorka przyjęła, że strategia to „wybrany świadomie jako konsekwencja misji, względnie trwały i spójny wzorzec zachowania się organizacji w otoczeniu” 22 , albo inaczej „ustalanie długofalowych celów (strategicznych) i sposób ich realizacji”23.

Określenie wizji i misji to elementy składające się na proces zarządzania strategicznego. Ponadto proces ten obejmuje analizę otoczenia oraz własnego potencjału (bardzo popularną metodą jest tutaj analiza SWOT - mocnych i słabych stron oraz szans i zagrożeń), wyznaczanie celów, opracowanie planu strategicznego uwzględniającego alokację zasobów oraz określenie najważniejszych zadań służących realizacji zakładanych celów ${ }^{24}$.

W literaturze przedmiotu przedstawiono wiele modeli zarządzania strategicznego, odnosząc je głównie do przedsiębiorstw. Różnią się one sposobem podejścia do planowania i zarządzania strategicznego. Żaden jednak z modeli nie pomija następujących etapów:

1. Analiza strategiczna, koncentrująca się na oczekiwaniach interesariuszy i misji organizacji, na zasobach organizacji oraz jej otoczeniu,

${ }^{17}$ Zob. http://mfiles.pl/pl/index.php/Planowanie_strategiczne (dostęp: 1.02.2016).

${ }^{18}$ M. Dragićević-Śeśić, B. Stojković, Kultura, zarządzanie, animacja, marketing, Warszawa 2010, s. 62.

${ }^{19}$ J. Penc, Strategie zarządzania. Perspektywiczne myślenie. Systemowe działanie, Warszawa 1994, s. 209

${ }^{20}$ Zob. hasło wizja, w: Koch, Stownik zarzadzania, s. 280-281.

${ }_{21}$ Zarządzanie. Teoria i praktyka, red. A.K. Koźmiński, W. Piotrowski Warszawa 2000, s. 353-354.

${ }^{22}$ Tamże, s. 42.

${ }^{23}$ Tamże, s. 82.

${ }^{24}$ Zob. hasło Proces planowania strategicznego, w: Encyklopedia zarządzania, op. cit.; http:// mfiles.pl/pl/index.php/Proces_planowania_strategicznego (dostęp: 5.10.2015). 
2. Wybór strategii, obejmujący generowanie opcji strategicznych, ocenę tych opcji oraz wybór optymalnego wariantu strategii,

3. Implementacja, obejmująca planowanie zasobów niezbędnych do wdrożenia strategii, określenie koniecznych zmian struktury organizacyjnej, opracowanie systemów motywacyjnych i kontrolnych, służących realizacji strategii ${ }^{25}$.

Wracając do misji należy zaznaczyć też, że w literaturze ${ }^{26}$ wskazuje się, aby misje były tworzone nie tylko przez kierownictwo, ale też przy zaangażowaniu pracowników danej instytucji, a także, aby ich treść była upowszechniona - zarówno wewnątrz, jak również i na zewnątrz, np. poprzez zamieszczenie jej na stronie internetowej. Jednak, jak wskazuje w swoich badaniach nad barierami przy opracowaniu misji instytucji kultury M. Lewandowski, przy formułowaniu misji przez pracowników mogą pojawiać się trudności takie jak:

- wybór słownictwa i użycie terminologii właściwej dla zarządzania kulturą,

- niektóre sformułowania wydają się zbyt banalne czy oczywiste, jednak ich upraszczanie prowadzi do rozmycia misji i wizji,

- chęć powiedzenia wszystkiego jednocześnie, co sprawiało, że stawały się one zbyt długie i przegadane,

- $\quad$ sprecyzowanie głównych, kluczowych haseł misji,

- ujęcie myśli w słowa, tak żeby nie pomieszać misji z wizją,

- wykonywana praca ukierunkowuje formułowanie treści misji i wizji,

- rozróżnienie wizji od misji nie w teorii, ale na etapie jej formułowania,

- mylenie misji z celami statutowymi organizacji,

- ujęcie wszystkich ważnych aspektów w jedno syntetyczne zdanie przy jednoczesnym zabezpieczeniu unikalności i atrakcyjności tej wizji ${ }^{27}$.

Ponadto M. Lewandowski identyfikuje bariery przy opracowywaniu misji, do których zalicza m.in.:

- rozróżnienie istoty misji i wizji,

- niedostrzeganie sensu formułowania obu elementów,

- brak uwzględnienia w misji społecznych efektów działalności kulturalnej,

- nieumiejętność grupowania działań instytucji według kryterium potrzeb społecznych zaspokajanych przez świadczone usługi i produkty kulturalne ${ }^{28}$.

Powyższe problemy, pojawiające się przy formułowaniu misji przez pracowników instytucji kultury, są również zauważalne przez autorkę w treściach analizowanych misji muzeów.

${ }^{25}$ B. Kożuch, Zarządzanie publiczne $w$ teorii i praktyce polskich organizacji, Warszawa 2004 , s. 182-184, przytoczyła za: Z. Pierścionek, Strategie rozwoju firmy, Warszawa 1997, s. 82-85.

${ }^{26}$ Por. np. H. Aarts, K. Plaisier, Zarzadzanie strategiczne, w: Nowoczesne zarzadzanie muzeum Wspótpraca polsko-holenderska w ramach projektu MATRA 1999-2007, Warszawa 2007, s. 28; R. Batko, R. Kotowski, Nowoczesne muzeum. Dziedzictwo i współczesność, Kielce 2010, s. 22-23, 30; K. Brańska, Misja jako narzędzie przezwyciężania wspótczesnych aporii muzealnych, w: Ekonomia muzeum, red. D. Folga-Januszewska, B. Gutowski, Kraków 2011, s. 180.

${ }^{27}$ Lewandowski, Czynniki utrudniające, s. 67.

${ }^{28}$ Tamże. 


\section{Misja a kontrola zarządeza}

Być może do zmian w zakresie tworzenia misji i wyznaczania celów muzeów publicznych przyczyni się obowiązek kontroli zarządczej. Reforma finansów publicznych z 2009 r. wprowadziła pojęcie kontroli zarządczej w jednostkach sektora finansów publicznych, a więc również w muzeach publicznych. Komunikat Ministra Finansów w sprawie standardów kontroli zarządczej dla sektora finansów publicznych wyznacza standardy, jakie powinna spełniać jednostka sektora finansów publicznych w pięciu obszarach ${ }^{29}$.

$\mathrm{Z}$ punktu widzenia omawianego tematu najważniejsze są zapisy standardu 2 - Cele i zarządzanie ryzykiem. Zgodnie bowiem ze szczegółowymi wytycznymi Ministra Finansów w zakresie zarządzania ryzykiem ${ }^{30}$, instytucje powinny przy planowaniu działalności określać swoją misję i wyznaczać cele działalności:

Jasne określenie misji może sprzyjać ustaleniu hierarchii celów i zadań oraz efektywnemu zarządzaniu ryzykiem. Należy rozważyć możliwość wskazania celu istnienia jednostki w postaci krótkiego i syntetycznego opisu misji. Misja (...) powinna odnosić się do działów administracji rządowej kierowanych przez ministra, a misja urzędu jednostki samorządu terytorialnego odpowiednio do tej jednostki. (...) Misja określa najważniejszy powód istnienia jednostki, najważniejszy cel w zakresie świadczenia usług dla obywateli. Tworząc misję można rozważyć takie kwestie jak: czym jednostka powinna się zajmować, co chce oferować obywatelom. Jednostka może także posiadać wizję, która określa jak chce być postrzegana. Misja czy wizja nie muszą być spisane w postaci formalnego dokumentu. Jednakże forma pisemna daje możliwość upowszechnienia misji i wizji jednostki w szerszym kręgu odbiorców ${ }^{31}$.

Tyle wytyczne i zalecenia ministra finansów względem instytucji publicznych, jak się jednak okazuje, praktyka formułowania misji nie jest powszechna, skoro jedynie 83 muzeów publiczne w Polsce ma sformułowaną misję swojej działalności.

\section{Misje a specyfika działalności muzeów}

Podstawowym wyróżnikiem muzeów spośród wszystkich instytucji kultury jest posiadanie kolekcji zbiorów. Rzeczy ruchome i nieruchomości stanowiące

${ }^{29}$ Określone obszary to: środowisko wewnętrzne, cele i zarządzanie ryzykiem, mechanizmy kontroli, informacja i komunikacja, monitorowanie i ocena. „Komunikat Nr 23 Ministra Finansów z dnia 16 grudnia 2009 r. w sprawie standardów kontroli zarządczej dla sektora finansów publicznych”, Dziennik Urzędowy Ministra Finansów nr 15 z 30 grudnia 2009, http://www.mf.gov.pl/documents/764034/1194475/DZIENNIK+URZĘDOWY+MINISTRA+FINANSÓW+NR+15+Z+DNIA+30+GRUDNIA+2009+R. (dostęp: 29.01.2016).

${ }^{30}$ Dziennik Urzędowy Ministra Finansów z dnia 18 grudnia 2012 r. Poz. 56, Komunikat nr 6 z dnia 6 grudnia 2012 w sprawie szczegółowych wytycznych dla sektora finansów publicznych w zakresie planowania i zarządzania ryzykiem", s. 5-6. http://www.mf.gov.pl/documents/764034/1095334/Dz.+Urz.+Min.+Fin.+z+dnia+18+grudnia+2012+r.+-+poz.+56+- , str. 5-6, (dostęp: 29. 01. 2016).

${ }^{31}$ Komunikat $\mathrm{nr} 6 \mathrm{z}$ dnia 6 grudnia $2012 \mathrm{w}$ sprawie szczegółowych wytycznych dla sektora finansów publicznych w zakresie planowania i zarządzania ryzykiem”, s. 5. 
własność muzeum i wpisane do inwentarza to muzealia. Prowadzona przez muzea działalność opiera się na posiadanych przez nie zbiorach. Zbiory są gromadzone, katalogowane i naukowo opracowywane, przechowywane $\mathrm{w}$ odpowiednich warunkach, konserwowane w celu ich zachowania w jak najlepszym stanie. Służą one w prowadzonej przez muzea działalności edukacyjnej i upowszechniania, a także są na różne sposoby udostępnianie. Jak pisze Jarosław Klaś:

Spośród innych organizacji kulturalnych muzea wyróżnia posiadanie kolekcji będącej ich podstawowym i najistotniejszym zasobem. Pomiędzy charakterem zbiorów a misją istnieje bezpośrednie powiązanie. Formułowanie misji powinno więc ściśle łączyć się z wyznaczeniem zakresu zbiorów z jednej strony, z drugiej natomiast, ponieważ „zbiory są emanacją misji” ”22, więc może być ona przydatna przy kształtowaniu zbiorów, kategoryzacji i ocenie przydatności do kolekcji, a w dalszej kolejności w decydowaniu o wymianie, sprzedaży lub pozyskaniu nowych obiektów ${ }^{33}$.

Ogólna charakterystyka posiadanych zbiorów, najczęściej w postaci spisu poszczególnych typów muzealiów jest określana w statutach tych muzeów. Formułuje się $\mathrm{w}$ ten sposób profil zbiorów, stanowiący o charakterze działalności danego muzeów i jego odrębności wobec innych instytucji kultury, w tym innych muzeów.

Jednak zależność między zbiorami a misją ma jeszcze jeden wymiar - jak określa to Katarzyna Barańska ma ono charakter „sprzężenia zwrotnego”, a (...) misja jest najistotniejszym czynnikiem kształtującym kolekcję i sposób jej rozbudowywania. Jeśli bowiem zbiory muzeum nie są tworzone w odniesieniu do zapisanego w odpowiednich dokumentach sformułowania misji, można obawiać się zagrożenia ich zbanalizowania i wkroczenia w obszary (...) które należałoby nazwać ,zbieractwem”, miast świadomym i odpowiedzialnym kolekcjonowaniem ${ }^{34}$.

Dlatego misja oraz jasno zdefiniowany profil zbiorów to najważniejsze czynniki stanowiące o odrębności i charakterze prowadzonej przez dane muzeum działalności. Przy czym możliwe jest, aby zarówno jedno, jak i drugie zostało zapisane w statucie. Jednak, o ile w statutach muzeów znajdują się zapisy odnośnie kolekcji zbiorów, o tyle wpisanie misji nie jest praktykowane. Autorka znalazła tylko jeden taki przykład - w Muzeum Narodowym w Krakowie ${ }^{35}$.

\section{Misje w polskich muzeach - analiza zjawiska}

Badanie przeprowadzono w oparciu o bazę muzeów opracowaną przez Narodowy Instytut Muzealnictwa i Ochrony Zbiorów, w której znajduje się 519

${ }^{32}$ M. Borusiewicz M., Muzeum - instytucja zaufania publicznego, w: Nowoczesne zarzadzanie muzeum. Wspótpraca polsko-holenderska w ramach projektu MATRA 1999-2007, red. J. Czaj, thum. tekstów holenderskich A. Tol-Pawłowska, Warszawa 2007.

${ }^{33}$ J. Klaś, Misja instytucji kultury na przykładzie muzeum - po co i jak ją tworzyć, „Zarządzanie w kulturze", 17 (2016) z. 1, s. 7.

${ }^{34} \mathrm{~K}$. Barańska, Muzeum w sieci znaczeń. Zarządzanie z perspektywy nauk humanistycznych, Kraków 2013, s. 75.

${ }^{35}$ Por. misja http://mnk.pl/misja-strategia-i-statut oraz par. 6 statutu Muzeum Narodowego w Krakowie (dostęp: 29.12.2016). 
publicznych i prywatnych muzeów polskich ${ }^{36}$. Podczas dokonywania przeglądu danych okazało się, że 70 muzeów (w tym 57 prywatnych) nie posiada własnych stron internetowych. Misji tych muzeów poszukiwano przez wyszukiwarkę internetową. Wśród wszystkich muzeów 88 ma określone misje swojej działalności, w tym 69 muzeów zamieściło ją na własnej stronie internetowej, natomiast $8 \mathrm{w}$ Biuletynie Informacji Publicznej, a $11 \mathrm{w}$ innym miejscu w sieci (inne strony www, dokumenty programowe etc.). Posiłkując się klasyfikacją rodzajową GUS ${ }^{37}$, która wyróżnia 16 rodzajów muzeów, można stwierdzić, że wśród 844 muzeów w Polsce ${ }^{38}$ około $10 \%$ ma sformułowaną misję swojej działalności. Wykres nr 1 pokazuje, jaki procent $\mathrm{w}$ poszczególnych typach muzeów posiada swoje misje. Najwięcej (19\%) to skanseny, następnie muzea literackie i martyrologiczne (po $17 \%)$, a najmniej muzea techniki i nauki $(6 \%)$ oraz geologiczne i przyrodnicze $(0 \%)$. Prezentuje to wykres nr 1.

\section{Wykres nr 1. Udział muzeów w Polsce posiadających misje w ogólnej liczbie muzeów, w podziale na typy muzeów.}

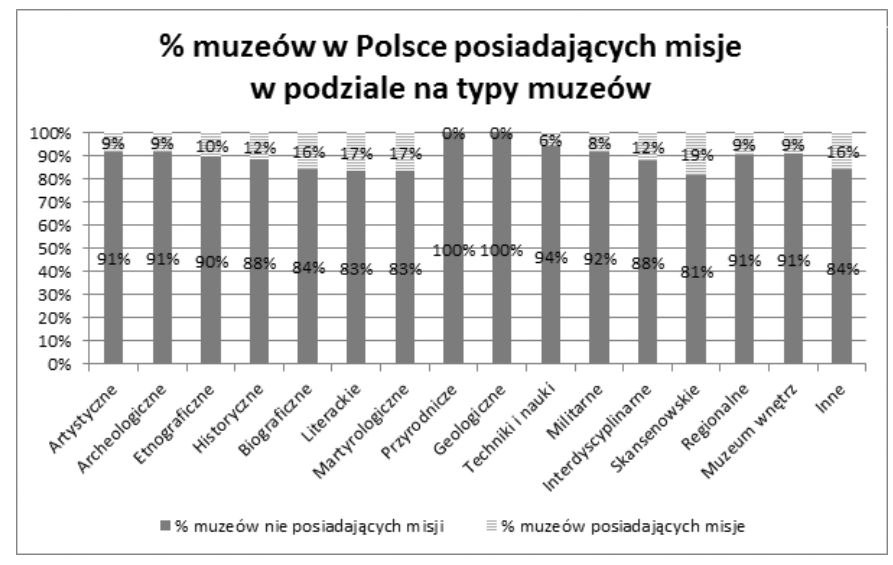

Źródło: Opracowanie własne na podstawie danych GUS.

Wykres nr 2 przedstawia analizowane zjawisko pod kątem organizatora. Najwięcej, bo $19 \%$ muzeów posiadających misje jest wśród muzeów współprowadzonych - tzn. posiadających więcej niż jednego organizatora. Następne, po 13\% wśród muzeów samorządowych (gminnych i wojewódzkich) oraz państwowych. Najmniej muzeów posiadających misje jest wśród muzeów prywatnych (3\%).

${ }^{36}$ Stan na koniec czerwca 2015 r.

${ }^{37}$ Formularz K-02: Sprawozdanie z działalności muzeum i instytucji paramuzealnej, http:// form.stat.gov.pl/formularze/2015/passive/K-02.pdf (dostęp: 29.09.2015).

${ }^{38}$ Dane GUS na koniec 2014 r. 
Wykres nr 2. Muzea w Polsce posiadające misje według organizatora.

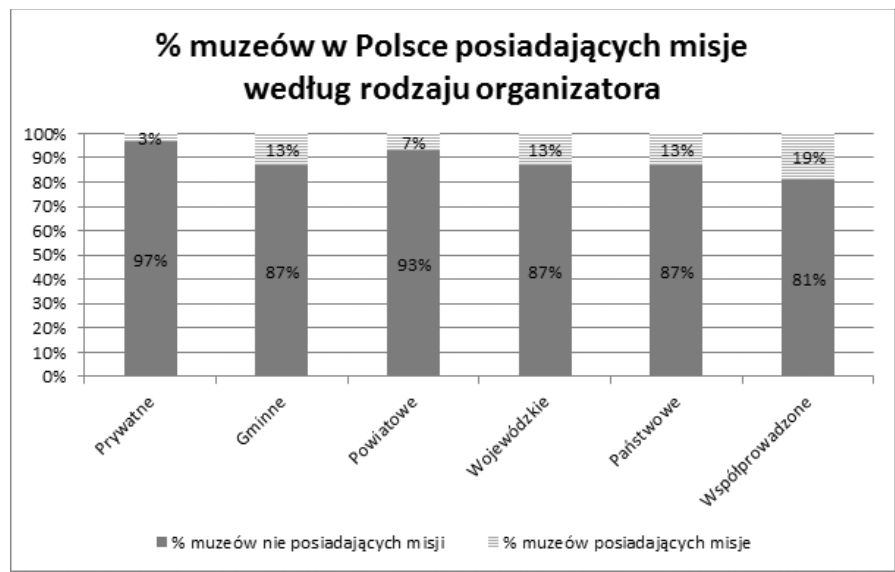

Źródło: Opracowanie własne na podstawie danych GUS.

Największy udział muzeów posiadających misję w ogólnej liczbie muzeów w danym województwie przypada na województwo lubuskie (18\%), dalej mazowieckie i podkarpackie (po 14\%) oraz małopolskie i śląskie (po 13\%). Najmniej muzeów posiadających misję jest w województwie warmińsko-mazurskim (3\%). Prezentuje to wykres nr 3.

Wykres nr 3. Muzea w Polsce posiadające misje według województw.

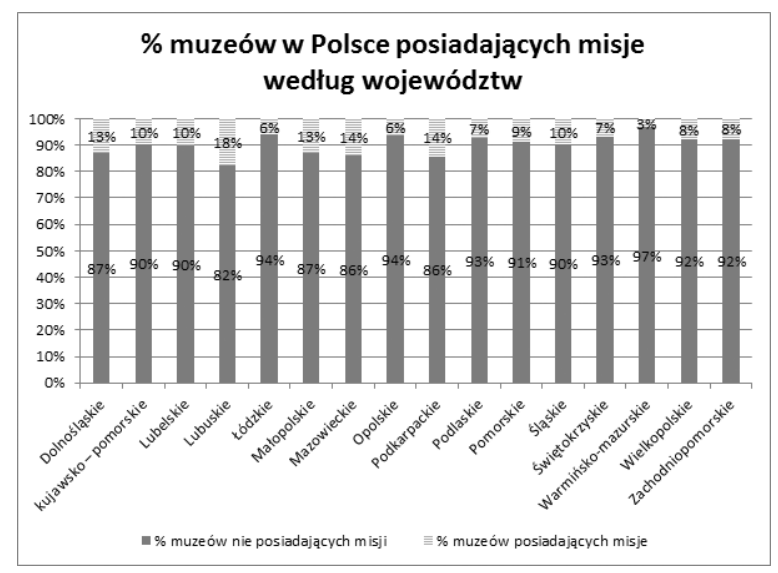

Źródło: Opracowanie własne na podstawie danych GUS.

Prawie we wszystkich misjach znajdują się odniesienia do specyfiki prowadzonej działalności, tematyki zbiorów czy zakresu (historycznego, geograficznego) ich aktywności. Równie często pojawiają się zapisy odnośnie form prowadzonej działalności, np. wystawy, publikacje, organizacja wydarzeń kulturalnych, 
zajęcia edukacyjne, etc. Głównym punktem odniesienia dla tworzonych misji były zapisy ustawy o muzeach ${ }^{39}$, określające definicję muzeum i jej cele (art.1) oraz sposoby realizacji tych celów (art. 2). Niektóre zapisy wprost mówiły, że misja jest określona w statucie, np. Muzeum Katyńskie, Muzeum im. Kłosińskiego w Kętach ${ }^{40}$, inne natomiast - w mniejszym lub większym stopniu - nawiązywały do zapisów ustawowych, np. misja Muzeum Miejskiego w Suchej Beskidzkiej:

Misją muzeum jest gromadzenie oraz trwała ochrona dóbr naturalnego i kulturowego dziedzictwa miasta Sucha Beskidzka o charakterze materialnym i niematerialnym ${ }^{41}$,

i nieco inne, ale powtarzające się sformułowanie to „misją (tu określenie identyfikujące muzeum) jest gromadzenie i ochrona materialnego i duchowego dziedzictwa kulturowego" (tu określenie identyfikujące region lub zakres tematyczny prowadzonej działalności ${ }^{42}$ Autorka przytacza powyższe przykłady, aby pokazać różne podejścia muzeów publicznych w Polsce do formułowania misji własnej działalności. Jednak należy zwrócić uwagę, że zapisy te - jakkolwiek określane przez muzea jako misje prowadzonej przez nie działalności - nie wpisują się $\mathrm{w}$ pojęcie misji $\mathrm{w}$ znaczeniu o jakim mowa $\mathrm{w}$ artykule. $\mathrm{W}$ większości zapisów pojawia się sformułowanie, w jaki sposób misja będzie realizowana. W tym miejscu najczęściej znajdują się odwołania do sposobów realizacji celów muzeów, określonych w ustawie (artykuł 2. ustawy o muzeach). W 17 misjach znajdują się bezpośrednie odniesienia do grupy docelowej prowadzonej działalności programowej. Najczęstsze sformułowania to odbiorcy (8 muzeów), zwiedzający (3 muzeów) oraz widzowie, publiczność, klienci czy ogólnie społeczeństwo. Trzy muzea dostrzegają potrzeby niepełnosprawnych, o których wprost mówią w swoich misjach (Muzeum L. Wyczółkowskiego w Bydgoszczy, Muzeum Regionalne w Stalowej Woli, Muzeum Sprzętu Gospodarstwa Domowego w Ziębicach). Większość zapisów ogranicza się do stwierdzenia, że ich rolą jest upowszechnianie czy udostępnianie zbiorów. Zważywszy m.in. na dyskusje toczące się na temat zadań i roli współczesnych muzeów w społeczeństwie oraz zmiany zachodzące $\mathrm{w}$ muzealnictwie, zauważalny jest stosunkowo niski poziom zapisów odnoszących się do potrzeb zwiedzających, czy oferty do nich kierowanej. Większy nacisk i akcenty w zapisach misji są kładzione na gromadzenie, opiekę i ochronę, naukowe opracowanie zbiorów, a zwłaszcza ich zachowanie dla przyszłych pokoleń. Co jednak ciekawe, pojęcie zbiory pojawia się zaledwie w 8 misjach, natomiast zdecydowanie częściej używane jest pojęcie dziedzictwo (31

\footnotetext{
${ }^{39}$ Ustawa o muzeach z 21 listopada 1996 r., Dz. U. 1997 Nr 5 poz. 24., http://isap.sejm.gov.pl/ DetailsServlet?id=WDU19970050024 (dostęp: 25.09.2015).

${ }^{40}$ Muzeum Katyńskie - http://www.muzeumkatynskie.pl/pl/23221/misja_muzeum_katynskiego.html (dostęp: 22.09.2015); Muzeum im. Kłosińskiego w Kętach - http://www.muzeum.kety.pl/ misja (dostęp: 22.09.2015).

${ }^{41}$ Misja Muzeum Miejskiego w Suchej Beskidzkiej - http://muzeum.sucha-beskidzka.pl/misja_muzeum.html (dostęp: 22.09.2015).

${ }^{42}$ Muzeum Ziemi Kłodzkiej - http://muzeum.klodzko.pl/nasza-misja (dostęp: 22.09.2015); Muzeum Ziemi Lubuskiej w Zielonej Górze - http://www.mzl.zgora.pl/index.php?url=misja_muzeum (dostęp: 22.09.2015).
} 
misji zawiera to określenie) i to zarówno w wymiarze materialnym, jak i niematerialnym, jako określenie odnoszące się do specyfiki prowadzonej działalności. Występuje ono w sformułowaniach ,dziedzictwo kulturowe”43, „dziedzictwo lokalne" ${ }^{44}$, ,dziedzictwo przeszłości ${ }^{45}$ " albo odnosi się do pewnego obszaru w sensie geograficznym ${ }^{46}$. Stosunkowo popularne pojęcia to: „tożsamość” (w misjach 15 muzeów) oraz „pamięć”, które występuje w 13 misjach, i to nie tylko tych o charakterze martyrologicznym, ale również biograficznym ${ }^{47}$. Muzea, poprzez sformułowania misji, postrzegają swoją rolę jako instytucji ważnej w kształtowaniu tożsamości odbiorców, również w kontekście miejsca. Często pojawiało się określenie budowania tożsamości mieszkańców: miasta, np. Tychy ${ }^{48}$, czy regionu, np. Pomorza Zachodniego ${ }^{49}$. Kilkakrotnie pojawia się też określenie kształtowania tożsamości człowieka. Jedną z pierwszych misji, zawierających to określenie, opracowaną w roku 2005 jest misja Muzeum Historycznego Miasta Krakowa ${ }^{50}$.

Analizując teksty misji należy zauważyć, że większość z nich ma rozbudowany, opisowy charakter, zawierający odwołania do specyfiki prowadzonej działalności, często prezentujący najważniejsze jej elementy, czy atuty. W konstrukcji misji pojawia się stwierdzenie, że misja jest realizowana poprzez: ... - tu zwykle następuje wypunktowanie działań programowych podejmowanych przez te instytucje. Widoczne są związki z zapisami ustawowymi, czy wręcz powielanie ich fragmentów, a także podobieństwo zapisów misji kilku muzeów, np.

Misja Muzeum Historycznego Miasta Krakowa to:

Jesteśmy po to by poznawać, chronić, przybliżać współczesnym i przekazać naszym następcom niepowtarzalne dziedzictwo przeszłości Krakowa. Nasza praca to służba na polu kształtowania człowieka świadomego swej tożsamości ${ }^{51}$.

${ }^{43}$ Przykładem jest misja Muzeum Historii Fotografii w Krakowie, w której mowa o dbaniu o powierzone dziedzictwo kulturowe, http://www.mhf.krakow.pl/?action=aboutmuseum\&param=mission (dostęp: 22.09.2015).

${ }^{44}$ Takie określenie pojawia się w np. w misji Muzeum im. W. Łęgi w Grudziądzu http://muzeum.grudziadz.pl/strona-185-misja.html (dostęp: 30.09.2015).

${ }_{45}$ Misja Muzeum Zamek w Łańcucie http://www.mz-lancut.bip.podkarpackie.pl/index.php/ dzialalnosc (dostęp: 30.09.2015).

${ }^{46} \mathrm{~Np}$. Misja Muzeum Zamojskiego mówi o dziedzictwie miasta Zamość oraz regionu zamojskiego, http://muzeum-zamojskie.pl/misja-muzeum (dostęp: 30.09.2015), a w misji Muzeum Śląska Cieszyńskiego jest wskazana ochrona dziedzictwa Śląska Cieszyńskiego w jego historycznych granicach. http://muzeumcieszyn.pl/index.php?option=com_content\&task=view\&id=149\&Itemid=126 (dostęp: 30.09.2015).

${ }^{47}$ Muzeum Dom Rodzinny Jana Pawła II, Muzeum Fryderyka Chopina, Muzeum Pułaskiego w Warce, Muzeum Z. Nałkowskich w Wołominie.

${ }^{48}$ Misja Muzeum Miejskiego w Tychach http://www.muzeum.tychy.pl/index.php?option=com_content\&task=blogcategory\&id=58\&Itemid=136 (dostęp: 30.09 .2015$)$.

${ }^{49}$ Misja Muzeum Narodowego w Kołobrzegu http://www.muzeum.szczecin.pl/o-muzeum/misja-statut.html (dostęp: 30.09.2015).

${ }^{50}$ Misja Muzeum Historycznego Miasta Krakowa http://www.mhk.pl/o-muzeum (dostęp: 30.09.2015).

${ }^{51}$ Muzeum Historyczne Miasta Krakowa http://www.mhk.pl/misja-i-historia (dostęp: 22.09.2015). 
Misja Muzeum Historycznego w Ełku brzmi:

Jesteśmy po to, by poznawać, chronić, przybliżać współczesnym i przekazać naszym następcom niepowtarzalne wielokulturowe dziedzictwo Ełku i Mazur. Naszą misja jest służba na polu kształtowania człowieka świadomego swej tożsamości i otwartego na tożsamość innych ludzi ${ }^{52}$.

A misja Muzeum Regionalnego w Kutnie jest następująca:

Jesteśmy po to by poznawać, chronić oraz przybliżać współczesnym i przekazać następnym pokoleniom dziedzictwo przeszłości Kutna i regionu. Nasza praca to służba na polu kształtowania człowieka świadomego swej tożsamości. Nasz cel to nowoczesne Muzeum XXI wieku ${ }^{53}$.

Analizując misje w kontekście funkcji muzeów należy stwierdzić, że w sformułowaniach dominują zapisy odnoszące się do gromadzenia, ochrony i naukowego opracowania zbiorów, a w dalszej dopiero kolejności dotyczące edukacji czy ukierunkowanych na odbiorców. Ciekawe podejście do formułowania misji wykazują muzea miejskie (Muzeum Miasta Gdyni, Muzeum Sztuki w Łodzi), które definiują cele swojej działalności przez pryzmat miasta, i silnie akcentują swoją społeczną rolę w przestrzeni publicznej. W tekstach misji dwóch muzeów można znaleźć odniesienia do zarządzania - Muzeum Narodowe w Kielcach realizuje swoją misję poprzez nowoczesność rozumianą jako: wprowadzenie systemu zarządzania jakością, zarządzania projektowego oraz narzędzi informatycznych wspomagających komunikację z klientami i realizację procesów ${ }^{54}$, natomiast Muzeum Oręża Polskiego w Kołobrzegu realizuje projekty promocyjne i marketingowe zwiększające dostępność obiektu dla zwiedzających ${ }^{55}$. Również muzea posiadające status „w organizacji” określają misję swojej działalności; tak jest w przypadku 5 muzeów.

\section{Treść misji a zapisy statutowe muzeów}

Ustawa o muzeach ${ }^{56}$ stanowi, że organizator powołując muzeum nadaje mu statut, który określa w szczególności zakres działania muzeum ${ }^{57}$ oraz rodzaj i zakres gromadzonych zbiorów ${ }^{58}$. Misje, opisujące najważniejszy cel istnienia instytucji, powinny być powiązane z zapisami statutów i z nimi korespondować. Trudno jednak, ze względu na objętość artykułu, dokonać tutaj szczegółowej analizy wszystkich statutów, wszystkich muzeów, które posiadają misje. Dlatego autorka dokonała porównania statutów muzeów w zakresie ich działania oraz rodzaju gromadzonych zbiorów z zapisami misji na poziomie bardziej ogólnym - typów

\footnotetext{
${ }^{52}$ Muzeum Historyczne w Ełku http://mhe-elk.pl/?muzeum,1 (dostęp: 22.09.2015).

${ }^{53}$ Muzeum Regionalne w Kutnie http://www.muzeumkutno.com/?cat=70 (dostęp: 22.09.2015).

${ }^{54}$ Muzeum Narodowe w Kielcach http://mnki.pl/pl/o_muzeum/misja/ (dostęp: 22.09.2015).

${ }^{55}$ Muzeum Oręża Polskiego w Kołobrzegu http://www.muzeum.kolobrzeg.pl/wokol-muzeum/ historia (dostęp: 22.09.2015).

${ }^{56}$ Ustawa o muzeach z dnia 21 listopada 1996 r., Dz. U. 1997 Nr 5 poz. 24, http://isap.sejm.gov. pl/DetailsServlet?id=WDU19970050024 (dostęp: 23.12.2016).

${ }^{57}$ Tamże.

${ }^{58}$ Tamże.
} 
muzeów. Posłużyła się przy tym podziałem muzeów ze względu na profil ich działalności (profil zbiorów) wychodząc z założenia, że główny cel działalności (misja) muzeów jest ściśle związany z charakterystyką (typem) posiadanych zbiorów. Przykładowo głównym celem muzeów biograficznych jest prezentacja artefaktów związanych z daną osobą i epoką, w której żyła, a muzeów artystycznych gromadzenie dzieł sztuki. W ten sposób przedstawione zostały związki misji z zapisami statutów wybranych typów muzeów.

Analizowane muzea korzystają z określonego w ustawie (art. 2 ustawy) katalogu sposobów realizacji celów, przenosząc wybrane zapisy do swoich statutów. Dalej, wypełniając ustawowe zapisy, charakteryzują swój profil zbiorów. Te dwa elementy są również widoczne w misjach muzeów. Dodatkowo muzea sztuki współczesnej kładą nacisk na uczestnictwo w kulturze i relacje odbiorcy ze sztuką (np. Muzeum Sztuki w Łodzi ${ }^{59}$, czy Muzeum Sztuki Współczesnej we Wrocła$w{ }^{60}{ }^{60}$. Natomiast muzea sztuki dawnej zwracają uwagę na znaczenie dziedzictwa w kształtowaniu tożsamości (np. Muzeum Narodowe w Szczecinie ${ }^{61}$ ) oraz nośnika wartości (Muzeum Narodowe w Krakowie ${ }^{62}$ ).

Muzea biograficzne poszerzają wątki biograficzne związane z postacią, której ich zbiory dotyczą, o zagadnienia pokrewne, np. dotyczące konkretnego miejsca z ich życia np. Muzeum Józefa Piłsudskiego w Sulejówku ${ }^{63}$, czy „,Domu nad Łąkami" Zofii Nałkowskiej ${ }^{64}$. Zdarza się, jak w przypadku Muzeum im. Kazimierza Pułaskiego w Warce, że misja nie do końca koresponduje z celami określonymi w statucie, w którym to, nie ma odniesien do osoby patrona muzeum ${ }^{65}$. Inne natomiast widzą swoją misję przede wszystkim jako upamiętnianie czy kultywowanie pamięci o danej osobie (np. Muzeum Jana Pawła II w Wadowicach, czy Muzeum Fryderyka Chopina w Warszawie), co ma swoje odzwierciedlenie zarówno w ich misjach jak i statutach.

Muzea etnograficzne w zapisach statutowych odwołują się do takich wartości jak „kształtowanie wrażliwości poznawczej” (o czym jest również mowa w par 1 ustawy o muzeach), np. zapisy statutowe Muzeum Azji i Pacyfiku w Warszawie czy Muzeum Kultury Kurpiowskiej w Ostrołęce ${ }^{66}$, natomiast ich misje rozwijają

${ }^{59} \mathrm{http}: / / \mathrm{msl}$.org.pl/pl/muzeum.html (dostęp: 27.12.2016).

${ }^{60}$ Misja zawarta jest w Muzeum współczesne Wrocław. Koncepcja programowa opracowana przez Zespół Programowy: Piotr Krajewski, Dorota Monkiewicz, współpraca Jerzy Ilkosz. http:// muzeumwspolczesne.pl/mww/wp-content/uploads/2012/06/aKoncepcja-programowa-pln-i-en.pdf (dostęp: 27.12.2016).

${ }^{61} \mathrm{http}: / /$ muzeum.szczecin.pl/o-muzeum/misja-statut.html (dostęp: 27.12.2016).

${ }^{62} \mathrm{http}: / / \mathrm{mnk} . \mathrm{pl} / \mathrm{misja}$-strategia-i-statut (dostęp: 27.12.2016).

${ }^{63}$ Par 3 pkt. 2 statutu Muzeum Józefa Piłsudskiego w Sulejówku http://www.muzeumpilsudski. $\mathrm{pl} /$ o-muzeum/powolanie/dokumenty-zalozycielskie/statut (dostęp: 23.12.2016).

${ }^{64}$ Pkt. 2 zakresu działania muzeum Nałkowskich w Wołominie, określonego w jego statucie http://muzeumnalkowskich.pl/userfiles/file/statut.pdf (dostęp: 23.12.2016).

${ }_{65}$ Porównaj misję http://www.muzeumpulaski.pl/muzeum/muzeum-im-kazimierza-pulaskiego-i-jego-misja (dostęp: 23.12.2016) oraz par 6 i 7 statutu http://nbip.pl/muzeumpulaski/i/?i=20585 (dostęp: 23.12.2016).

${ }^{66}$ Zob. Par 6 statutu Muzeum Azji i Pacyfiku w Warszawie i par. 6 statutu Muzeum Kultury Kurpiowskiej w Ostrołęce. 
te wartości wskazując również na kontekst, tj. relacje między prezentowanymi kulturami, a kulturą lokalną (np. Muzeum Azji i Pacyfiku ${ }^{67}$ ). Misje i statuty muzeów skansenowskich odnoszą się do zbiorów (architektury i budownictwa ludowego, etnografii) prezentujących wybrany obszar geograficzny (np. Muzeum Wsi Mazowieckiej w Sierpcu ${ }^{68}$ ). Ciekawie sformułowana jest misja Muzeum Kultury Ludowej Pogórza Sudeckiego w Kudowej Zdroju, w której jest mowa o pograniczu i pokojowym współżyciu ludzi różnych narodowości, ${ }^{69}$ bez określenia obszaru geograficznego.

W przypadku muzeów militarnych ich misje parafrazują zapisy statutowe, określając obszar czasowy czy geograficzny działalności danego muzeum, czasem nawet w zakresie sposobu realizacji misji (celów statutowych), jak to ma miejsce w przypadku Muzeum Marynarki Wojennej ${ }^{70}$, gdzie sposób realizacji misji nawiązuje do sposobu realizacji celów określonych w statucie.

Misje muzeów martyrologicznych są zbieżne z zapisami statutów głównie w zakresie zapisów odnoszących się do upamiętniania ludności, która zginęła z rąk okupantów (np. Muzeum Stutthof, Żabikowo ${ }^{71}$ ) oraz opieki nad miejscami związanymi z tragicznymi losami ludności podczas II wojny światowej - obozami koncentracyjnymi, przejściowymi, czy pracy przymusowej.

Muzeum techniki traktują swoją działalność w szerokim znaczeniu - historii a także promocji regionu, gdzie są zlokalizowane. Tak jest w przypadku Muzeum Tkactwa w Kamiennej Górze, w misji oraz statucie którego zwraca się uwagę na promocję historii i kultury regionu ${ }^{72}$.

Muzea historyczne w swojej działalności kierują się takimi wartościami jak: kształtowanie tożsamości, ochrona pamięci czy upowszechnianie wiedzy historycznej. W misjach pojawia się określenie, że są miejscem spotkań (np. Muzeum Historyczne w Bielsku-Białej ${ }^{73}$ ), albo spotkań i dyskusji (np. Muzeum Emigracji w Gdyni, Muzeum Historii Fotografii ${ }^{74}$ ). Kładą również nacisk na prowadzoną działalność edukacyjną (np. Muzeum Historyczne w Bielsku-Białej). Ponadto w określeniu zakresu działalności oraz misjach pojawia się pojęcie digitalizacji albo cyfryzacji jako formy upowszechniania zbiorów (np. Muzeum Historii Polski, Muzeum Historyczne w Ełku ${ }^{75}$ ).

${ }^{67} \mathrm{http}: / /$ www.muzeumazji.pl/o-muzeum/misja/ (dostęp: 27.12.2016).

${ }^{68} \mathrm{http}: / /$ mwmskansen.pl/377/podpisanie-umowy-o-dofinansowanie-projektu-,,budowa-centrum-kulturalno-rekreacyjnego-w-muzeum-wsi-mazowieckiej-w-sierpcu (dostęp: 27.12.2016).

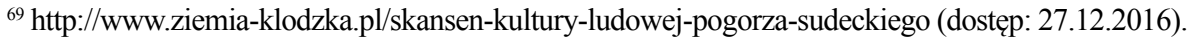

$70 \mathrm{http} / /$ www.muzeummw.pl/www/files/MISJA\%20MUZEUM\%20MARYNARKI\%20WOJENNEJ\%20W\%20GDYNI.pdf (dostęp: 27.12.2016).

71 http://pomorskie.travel/Odkrywaj-Dziedzictwo_kulturowe-Muzea/1631/Muzeum_Stutthof_w_Sztutowie oraz http://zabikowo.eu/muzeum/misja-muzeum (dostęp: 27.12.2016).

${ }^{72}$ Zob. misja http://www.nocowanie.pl/muzeum_tkactwa,142940.html (dostęp: 27.12.2016) oraz par. 5 statutu Muzeum.

${ }^{73} \mathrm{http}: / /$ muzeum.bielsko.pl/pl/misja_muzeum (dostęp: 28.12.2016).

${ }^{74} \mathrm{http}: / /$ www.polska1.pl/pl/omuzeum/idea i http://mhf.krakow.pl/?action=aboutmuseum\&param=mission (dostęp: 28.12.2016).

$75 \mathrm{http} / / /$ muzhp.pl/pl/c/8/informacje-o-muzeum-historii-polski oraz http://www.mhe-elk.pl/?muzeum,1 (dostęp: 28.12.2016). 
Podobnie widzą swój cel i miejsce w życiu lokalnych społeczności muzea regionalne. $\mathrm{W}$ misjach pojawia się określenie, że opiekują się lokalnym czy regionalnym dziedzictwem (np. Muzeum Zamojskie ${ }^{76}$ ); próbują również swoją działalność wpisać w szerszy kontekst sztuki i historii (np. Muzeum Regionalne w Stalowej Woli czy Muzeum Ziemi Wschowskiej ${ }^{77}$ ). Podobnie jak w przypadku muzeów historycznych, również w tekstach misji muzeów regionalnych pojawiają się wątki edukacyjne i tożsamościowe.

Powyższe zestawienie misji ze statutami muzeów o różnym profilu działalności wskazuje, że treść misji często poszerza i uzupełnia zapisy statutowe. Ponadto, o ile treść misji przez wiele muzeów jest wykorzystana do prezentacji swoich atutów czy refleksji nad celem i formami prowadzonej działalności, to zapisy statutowe ograniczają się do określeń wprost nawiązujących do artykułu 1 ustawy o muzeach.

\section{Podsumowanie}

Przeprowadzona analiza wykazała, że misje jako element zarządzania strategicznego nie są powszechne w polskich muzeach. Jak pisze M. Borusewicz, związane jest to $\mathrm{z}$ faktem, że „,dokument taki nie jest wymagany ani przepisami prawa, ani nie ma zwyczaju, by się z nim zapoznawać przy przydzielaniu grantów, dotacji czy innego wsparcia" ${ }^{78}$. A jeżeli są formułowane, to ściśle nawiązują do zapisów ustawy o muzeach, mają opisowy, rozbudowany charakter i zdecydowanie częściej odwołują się do funkcji opieki nad zbiorami, przekazywania dziedzictwa przyszłym pokoleniom niż do zaspokajania potrzeb odbiorców. Wskazane w pierwszej części artykułu trudności w formułowaniu misji, dają się również zauważyć w treści misji muzeów. Szczególnie dotyczy to mylenia misji z celami statutowymi oraz chęć przekazania wszystkich ważnych treści jednocześnie (brak hierarchizacji i dokonania wyboru, co jest najważniejsze). Dlatego wciąż aktualne pozostają stwierdzenia K. Barańskiej, która pisze „(...) Zdarza się jednak, że te sformułowania (tzn. deklaracja misji) są ogólnikowe i robią wrażenie nieco rozwiniętych celów zawartych w standardowym statucie"79.

Ponadto w przypadku analizowanych instytucji misja jest jedynym elementem zarządzania strategicznego w muzeach, który znany jest otoczeniu (za pośrednictwem Internetu). Bardzo rzadką praktyką jest zamieszczanie strategii na stronie internetowej muzeum. Dlatego potrzebne są dalsze, pogłębione badania w tym zakresie, a powyższy artykuł stanowi jedynie wstępną analizę zjawiska.

Słowa kluczowe: muzeum; misja muzeum; muzea w Polsce

${ }^{76}$ Zob. Misja Muzeum Zamojskiego http://muzeum-zamojskie.pl/misja-muzeum (dostęp: 28.12.2016).

${ }^{77}$ Misja Muzeum w Stalowej Woli http://muzeum.stalowawola.pl/pl/muzeum/misja, par 6 statutu Muzeum Ziemi Biłgorajskiej (dostęp: 28.12.2016).

${ }^{78}$ M. Borusewicz, Nauka czy rozrywka. Nowa muzeologia w europejskich definicjach muzeum, Kraków, 2012, str. 186.

${ }^{79} \mathrm{~K}$. Barańska Misja jako narzędzie przezwyciężania współczesnych aporii muzealnych, w: Ekonomia muzeum, red. D. Folga-Januszewska, B. Gutowski, Kraków 2011, str. 180. 


\section{BIBLIOGRAFIA}

Aarts Herman, Plaisier Kees, Zarządzanie strategiczne w: Nowoczesne zarządzanie muzeum Współpraca polsko-holenderska w ramach projektu MATRA 1999-2007, red. J. Czaj, Warszawa 2007, s. 28-47.

Barańska Katarzyna, Misja jako narzędzie przezwyciężania współczesnych aporii muzealnych, w: Ekonomia Muzeum, red. D. Folga-Januszewska, B. Gutowski, Kraków 2011, s.175-182.

Barańska Katarzyna Muzeum etnograficzne. Misje, struktury, strategie, Kraków 2004.

Barańska Katarzyna, Muzeum w sieci znaczeń. Zarządzanie z perspektywy nauk humanistycznych, Kraków 2013.

Barańska Katarzyna Wiatr w żaglach, czyli misja Muzeum Etnograficznego im. Seweryna Udzieli w Krakowie, ,Zarządzanie w kulturze”, 7 (2006) s. 15-23.

Batko Roman, Kotowski Robert, Nowoczesne muzeum. Dziedzictwo i współczesność, Kielce 2010.

Borusewicz Mirosław, Nauka czy rozrywka. Nowa muzeologia w europejskich definicjach muzeum, Kraków 2012.

Dragićević-Śeśić Milena, Stojković Branimir, Kultura, zarządzanie, animacja, marketing, Warszawa 2010.

Gaweł Łukasz Muzeum w przestrzeni publicznej. Przyczynek do praktyki zarządzania instytucjami kultury, „Zarzadzanie publiczne”,15 (2011) z. 3, s. 51-63.

Griffin Ricky, Podstawy zarzadzania organizacjami, Warszawa 1998.

Klaś Jarosław Misja instytucji kultury na przykładzie muzeum - po co i jak ją tworzyć, „Zarządzanie w kulturze,” 17 (2016) z. 1, s. 1-8.

Koch Richard, Słownik zarządzania i finansów. Narzędzia, terminy, techniki od A do Z, misja, wizja, Kraków 1997.

Kożuch Barbara Zarządzanie publiczne w teorii i praktyce polskich organizacji, Warszawa 2004.

Koźmiński Andrzej, Piotrowski Włodzimierz red., Zarządzanie. Teoria i praktyka, Warszawa 2013.

Lewandowski Mateusz, Czynniki utrudniające samodzielne opracowywanie planów strategicznych prze pracowników instytucji kultury, w: Zarządzanie w instytucji kultury, red. Ł. Wróblewski, Warszawa 2014.

Lewandowski Mateusz, Zarządzanie strategiczne w instytucjach kultury, Katowice 2013.

Matt Geralt, Muzeum jako przedsiębiorstwo. Łatwo i przystępnie o zarządzaniu instytucją kultury, Warszawa 2006.

Obłój Krzysztof, Strategia organizacji, Warszawa 1999.

Penc Józef, Strategie zarządzania. Perspektywiczne myślenie. Systemowe działanie, Warszawa 1994.

Zarządzanie w kulturze, sztuce i turystyce kulturowej, red. Gołuchowski Jerzy, Spyra Zbigniew, Warszawa 2014.

\section{Dokumenty elektroniczne}

Edukacja muzealna w Polsce. Sytuacja, kontekst, perspektywy rozwoju. Raport o stanie edukacji muzealnej w Polsce." http://nimoz.pl/pl/wydawnictwa/wydawnictwa-nimoz/raport-o-stanie-edukacji-muzealnej-w-polsce-4 (dostęp: 4.10.2015)

Encyklopedia zarządzania, http://mfiles.pl (dostęp: 5.10.2015)

Formularz K-02 Sprawozdanie z działalności muzeum i instytucji para muzealnej, http:// form.stat.gov.pl/formularze/2015/passive/K-02.pdf (dostęp: 25.09.2015) 
Komunikat Nr 23 Ministra Finansów z dnia 16 grudnia 2009 r. w sprawie standardów kontroli zarządczej dla sektora finansów publicznych, w: „Dziennik Urzędowy Ministra Finansów" nr 15 z 30 grudnia 2009 (dostęp: 5 stycznia 2016). http://www.mf.gov. $\mathrm{pl} /$ documents/764034/1194475/DZIENNIK+URZĘDOWY+MINISTRA+FINANSÓW+NR+15+Z+DNIA+30+GRUDNIA+2009+R. (dostęp: 29.01.2016)

Komunikat nr 6 z dnia 6 grudnia 2012 w sprawie szczegółowych wytycznych dla sektora finansów publicznych w zakresie planowania i zarzadzania ryzykiem w: „Dziennik Urzędowy Ministra Finansów” z dnia 18 grudnia 2012 r. Poz. 56 http://www. mf.gov.pl/documents/764034/1095334/Dz.+Urz.+Min.+Fin.+z+dnia+18+grudnia+2012+r.+-+poz.+56+-, str. 5-6, (dostęp: 29.01.2016)

Muzeum współczesne Wrocław. Koncepcja programowa http://muzeumwspolczesne.pl/mww/ wp-content/uploads/2012/06/aKoncepcja-programowa-pln-i-en.pdf (dostęp: 27.12.2016)

Ustawa o muzeach z 21 listopada 1996 r., Dz. U. 1997 Nr 5 poz. 24. http://isap.sejm.gov. pl/DetailsServlet?id=WDU19970050024 (dostęp: 25.09.2015)

Raport. Strategia rozwoju muzealnictwa. Założenia programowe, http://nimoz.pl/pl/dzialalnosc/prace-programowe-1/strategia-rozwoju-muzealnictwa (dostęp: 02.10.2015)

\section{Netografia}

Encyklopedia Zarządzania www.mfiles.pl

Główny Urząd Statystyczny www.stat.gov.pl (dostęp: 29.09.2015)

Ministerstwo Finansów www.mf.gov.pl (dostęp: 29.01.2016)

Muzeum Azji i Pacyfiku www.muzeumazji.pl (dostęp: 27.12.2016).

Muzeum Dom Rodzinny Jana Pawła II www.domjp2.pl (dostęp: 30.09.2015)

Muzeum Fryderyka Chopina www.chopin.muzeum.pl (dostęp: 30.09.2015)

Muzeum Historii Fotografii w Krakowie www.mhf.krakow.pl (dostęp: 22.09.2015)

Muzeum Historii Polski www.muzhp.pl (dostęp: 28.12.2016)

Muzeum Historyczne Miasta Krakowa www.mhk.pl (dostęp: 30.09.2015)

Muzeum Historyczne w Bielsku-Białej www.muzeum.bielsko.pl (dostęp: 28.12.2016)

Muzeum Historyczne w Ełku www.mhe-elk.pl (dostęp: 22.09.2015)

Muzeum Józefa Piłsudskiego w Sulejówku www.muzeumpilsudski.pl (dostęp: 23.12.2016)

Muzeum im. Aleksandra Kłosińskiego w Kętach www.muzeum.kety.pl (dostęp: 22.09.2015)

Muzeum im. ks. dr. Władysława Łęgi w Grudziądzu www.muzeum.grudziadz.pl (dostęp: 30.09.2015)

Muzeum Katyńskie www.muzeumkatynskie.pl (dostęp: 22.09.2015)

Muzeum Miejskie Suchej Beskidzkiej www.muzeum.sucha-beskidzka.pl (dostęp: 22.09.2015)

Muzeum Miejskie w Tychach www.muzeum.tychy.pl (dostęp: 30.09.2015)

Muzeum Nałkowskich w Wołominie www.muzeumnalkowskich.pl (dostęp: 30.09.2015)

Muzeum Narodowe w Kielcach www.mnki.pl (dostęp: 22.09.2015)

Muzeum Narodowe w Krakowie www.mnk.pl (dostęp: 29.12.2016)

Muzeum Narodowe w Szczecinie www.muzeum.szczecin.pl (dostęp: 27.12.2016).

Muzeum Oręża Polskiego w Kołobrzegu www.muzeum.kolobrzeg.pl (dostęp: 22.09.2015)

Muzeum Pułaskiego w Warce www.muzeumpulaski.pl (dostęp: 30.09.2015)

Muzeum Regionalne w Kutnie www.muzeumkutno.com (dostęp: 22.09.2015)

Muzeum Regionalne w Stalowej Woli www.muzeum.stalowawola.pl (dostęp: 28.12.2016)

Muzeum Śląska Cieszyńskiego www.muzeumcieszyn.pl (dostęp: 30.09.2015)

Muzeum Zamek w Łańcucie www.mz-lancut.bip.podkarpackie.pl (dostęp: 30.09.2015)

Muzeum Zamojskie w Zamościu www.muzeum-zamojskie.pl (dostęp: 30.09.2015)

Muzeum Ziemi Kłodzkiej www.muzeum.klodzko.pl (dostęp: 22.09.2015)

Muzeum Ziemi Lubuskiej www.mzl.zgora.pl (dostęp: 22.09.2015) 
Narodowy Instytut Muzealnictwa i Ochrony Zbiorów www.nimoz.pl (dostęp: 01.02.2016)

Słownik Języka Polskiego PWN, http://sjp.pwn.pl/szukaj/misja.html (dostęp: 01.02.2016)

\title{
A MISSION AS AN ELEMENT OF STRATEGIC MANAGEMENT FOR MUSEUMS
}

\begin{abstract}
Summary
Museums in Poland are developing dynamically and undergoing intensive transformations. More and more attention is paid to the issues of management, including the ones connected with a missionary role of museums. The concept of a mission is commonly identified with the purposes of museums and the main subject of their activity. The aim of this article is to analyze a mission as an element of strategic management for museums, as well as to identify the scale of the phenomenon of a mission formulated by Polish museums (how many of them have a formulated mission?), and to analyze the content of a mission, mainly with reference to the objectives included in the law on museums. The article discusses the results of the existing data analysis (the websites review and the Public Information Bulletin of museums which are in the database of the National Institute of Museums and Public Collections).
\end{abstract}

Keywords: a museum; the mission of a museum; museums in Poland 